\title{
R Programming Language
}

National Cancer Institute

\section{Source}

National Cancer Institute. R Programming Language. NCI Thesaurus. Code C69302.

A programming language and software environment for statistical computing and graphics. 